non-rotational forceps $47 \%$ controls, $31 \%$ in those receiving treatment). A significant reduction of at least $50 \%$, however, would be needed with 200 mothers studied to be interpreted with $80 \%$ degree of confidence. Conversely, if there were 500 mothers in each group a reduction of only $10 \%$ would be detected at 0.05 significance with $90 \%$ degree of confidence.

Secondly, the proportion of rotational deliveries in the controls was exceptionally small (9\%). This is most likely to be due to chance as other workers have reported figures in the region of $17-20 \%{ }^{2}$ (J S Smoleniec, personal communication), which is comparable with the incidence in the women receiving treatment $(18 \%)$. This probable false impression of a higher rate of rotational forceps deliveries with infusion of oxytocin in the second stage would also be resolved in a larger study.

Finally, the overall rate of forceps delivery in the controls $(56 \%)$ seems remarkably high. In Avon (where there are more than 10000 deliveries annually) the rate of forceps deliveries for primigravidas who use epidural anaesthesia during labour is $32 \%, 4$ and this is without a policy of second stage augmentation. Possible explanations for this may be the different ways in which second stage protocols are applied in different centres and factors relating to the epidural anaesthesia ${ }^{6}-$ for example, in Avon many mothers have a reduced concentration of local anaesthetic during the late stages of labour or have the drug administered as a continuous infusion to minimise the motor block.

J S SMOLENIEC D K JAMES

Bristol Maternity Hospital Bristol BS2 8EG

1 Saunders NJS, Spiby H, Gilbert L, et al. Oxytocin infusion during second stage of labour in primiparous women usin epidural analgesia: a randomised double blind placebo controlled trial. Br.Med f 1989;299:1423-6. (9 December.)

2 Goodfellow CF, Studd C. The reduction of forceps in primigravidae with epidural analgesia - a controlled trial. $\mathrm{Br}^{\mathrm{f}} \mathrm{Clin}$ Pract 1979;33:287-8.

3 Studd JWW, Crawford JS, Duignan NM, Robotham CHF, Hughes AO. The effect of lumbar epidural analgesia on the rate of cervical dilatation and the outcome of labour of spontaneous of cervical dilatation and the outcome of labouro

4 Anonymous. Avon perinatal report. Bristol: University of Bristol, 1988

5 Crawford JS. The effect of epidural block on the progress of labour. In: Studd J, ed. Progress in obstetrics and gynaecology. Vol 2. Edinburgh: Churchill Livingstone, 1982:90-2.

6 Hollmen A. Regional techniques of analgesia in labour. $\mathrm{Br} f$ Anaesth 1979;51:175-245.

\section{Rat bites and leprosy}

SIR,-In Dr T P Eddy's ghoulish account of rats biting the anaesthetic limbs of patients with leprosy ${ }^{1}$ he has overlooked a fundamental point Pain loss in patients with leprous polyneuropathy is confined to superficial tissues, and squeezing the Achilles tendon causes intense discomfort. As a rat's teeth would penetrate the deeper tissues the patients probably did feel pain, though they may not have complained: Nigerians, especially those from northern Nigeria, are renowned for being stoical. Other modalities of deep sensationsuch as vibration sense and proprioception-are also unaffected and the reflexes are preserved, unlike in patients with diabetic polyneuropathy. These observations in Norwegian patients with leprosy have been meticulously recorded by Monrad-Krohn in his extensive but sadly neglected monograph, ${ }^{2}$ and I have confirmed his findings in Nigerian patients.

These somewhat gruesome anecdotes ${ }^{+}$thus serve to illustrate important differences between diabetic and leprous polyneuropathy. Although patients with leprous polyneuropathy suffer loss of sweating, sympathetic activity as judged by the absence of postural hypotension is probably normal. "Yet trophic ulcers, distal tapering of the metatarsals ("sucked candy" appearance), and torsal disintegration can occur in patients with diabetic or leprous neuropathy. It could therefore be argued that autonomic neuropathy, which occurs in patients with diabetes, may not be a factor in the causation of these serious complications.

C L CRAWFORD

Department of Anatomy,

Charing Cross and Westminster Medical School,

London W6 8R

1 Eddy TP. Rat bites and leprosy. Br Med f 1989;299:1575 23-30 December.)

Monrad-Krohn GH. The neurological aspect of leprosy. Christiania, South Africa: Jacob Dybwad, 1923.

Crawford CL. Neurological lesions in leprosy. Lepr Rev 1968;39:

+ Cooles P, Paul H. Rat bites and diabetic foot in the West Indies. Br.Med f 1989;298:868. (1 April.)

Sabin TD. Neurological features of lepromatous leprosy. Am Fam Physician 1971;4:84.

\section{Congenital malformations}

SIR,-Remembering that the Medical Research Council has organised a multicentre trial on periconceptual vitamin supplementation and neural tube defects, it may be pertinent to point out that the Asian population studied by Drs Lyn Chitty and R M Winter ${ }^{1}$ is likely to have included a significant number of vegetarians, to have had an increased incidence of vitamin B-12 deficiency, and to have had significantly lower serum B-12 concentrations during pregnancy.

Division of Anaesthesia,

M J LANDON

Clinical Research Centre,

Harrow HA1 3UJ

1 Chitty L, Winter RM. Congenital malformations. $\mathrm{Br}$ Med $\mathcal{F}$ 1990;300:121-2. (13 January.)

Chanarin I, O'Hea A-M, Malkowska V, Rinsler MG, Price AB. Megaloblastic anaemia in a vegetarian Hindu community. Lancet 1985;ii:1168-72.

Abraham R, Brown MC, McFadyen IR. In: Bateman EC, ed. Applied nutrition. 11th ed. London: John Libby, 1984:94-8.

\section{Lack of knowledge has led to rift}

SIR,-Scrutator defends the General Medical Services Committee's decision not to debate my motion calling for a ballot on sanctions over the general practitioner contract, describing the decision as a damage limitation tactic rather than cowardice or weakness.' He goes on to assert that "it would be tactically foolish to ballot genera practitioners when the review body on pay is about to declare its judgment and when a special conference is only a month or so away and any result of the ballot would be unavailable."

Neither of these arguments hold water. Most objections to the contract are concerned with the imposition of clinical direction and increased administrative workload; a high pay award will not alter these factors. There was also ample time. The GMSC met on 18 January-nine weeks before the special conference. Last year's ballot on the contract took four weeks from start to finish.

It was claimed within the GMSC that there is no evidence that general practitioners would be willing to take sanctions. A ballot would have shown whether this assertion is correct. There is, however, the overwhelming evidence of last year's vote, which was reinforced by the results of the recent poll conducted by Doctor, ${ }^{2}$ that a large majority of general practitioners oppose the contract. Last April's special conference of local medical committees called on the GMSC to investigate sanctions if a satisfactory agreement was not reached.

I agree that it is right for the GMSC to advise general practitioners on how best to work the new regulations. But at the same time we should have seized the opportunity to allow the profession to make its discontent known in a practical way. By refusing to do so the GMSC has shown cowardice not only in the face of the enemy but also in front of those it is meant to lead and represent.

Those of us who proposed sanctions had in mind something that would not have harmed patient care-namely, refusal to carry out "lifestyle" checks on healthy adults. It is unlikely that this step would have changed Kenneth Clarke's mind, but it would have enabled us to register our dissent and might have helped to restore morale, which, as Scrutator points out, is falling rapidly. As it is we have handed $\mathrm{Mr}$ Clarke a propaganda victory because on 1 April he will be able to say that despite all the noise made last year general practitioners are working to his new contract without protest.

ERIC ROSE

Buckinghamshire HP21 7HH

1 Scrutator. Lack of knowledge has led to rift. Br Med 7 1990;300:218. (27 January.)

2 Anonymous. New contract poll. Doctor 1990 January 11

\section{Census of medical registrars on 14 February}

SIR, - Many fellows and members of the Royal College of Physicians have expressed their concern about the implications of the report on future staffing requirements in the training and consultant grades (Hospital Medical Staffing: Achieving a Balance-a Plan for Action). The college's present principal anxiety concerns the registrar grade. The Joint Planning Advisory Committee has suggested major cuts in the number of career registrars. This will have serious consequences for opportunities for training in hospital medicine in the United Kingdom as well as curtailing opportunities for training in research.

From our discussions with the advisory committee it is clear that there is a lack of accurate information on the numbers of registrars and honorary registrars. I am glad to say that the committee has agreed to delay fixing a quota for career registrars in general medicine for six months in order to give us time to produce accurate figures. We propose to do this by mounting a census of registrars who are training in general medicine and in most medical specialties on 14 February of this year. Census forms and detailed explanatory notes were distributed to college tutors in all health districts in England and Wales last week. The British Paediatric Association is undertaking a similar census of paediatric registrars on the same day.

An appointment in the registrar grade is valued highly by young doctors as offering excellent opportunities for clinical training. A similar appointment-funded by the Medical Research Council, a charitable foundation, or another source - with honorary registrar status provides an opportunity to learn about methods of clinical research. The Royal College of Physicians is most anxious that such opportunities should not be lost simply for reasons of inadequate documentation, and we very much hope that we will have the cooperation of all physicians and their registrars in completing the forms on census day.

Royal College of Physicians,

MARGARET TURNER-WARWICK London NW1 4LE

\section{Correction}

Oral contraceptives and diabetes mellitus

An authors' error occurred in the table of this authors' reply by Drs Philip C Hannaford and Clifford R Kay (20 January, p 196). The figures refer to duration of ever use (months) and not current use as published. 